\title{
NORMAS DE FORMATAÇÃO PARA ENVIO DE ARTIGOS
}

Papel: formato A4

Margens: Todas as margens $03 \mathrm{~cm}$.

Título: Centralizado, espaço simples, negrito, Calibri 14, em caixa alta. Espaço entre o título e os autores 1,5, tamanho 12 .

Sub-títulos (o que inicia as partes do texto): em negrito, calibri 12, dois espaços após o item anterior e um espaço antes do parágrafo seguinte. Norma culta da Língua. Usar controle de linhas órfãs e manter com o próximo.

Autor (es): (não esqueça de suprir o nome dos autores em "manuscrito" - arquivo que será enviado para avaliação cega): Parágrafo simples: alinhamento à direita. Sem espaço entre dois ou mais autores. Fonte: Calibri 12. Incluir nota biográfica de rodapé com a formação do autor, área de pesquisa; instituição de origem e e-mail (Calibri 10 - justificado).

Resumos (obrigatórios no "manuscrito" - arquivo submetido para avaliação): em Português e em outra língua opcional (Inglês, Espanhol, Francês, Italiano, etc.), com até 800 caracteres (com espaço), em espaço simples, sem citações e parágrafo único. Colocar um espaço simples entre autor e resumo. Fonte: Calibri 12.

Palavras-chave: 3 a 5, em português e outra língua. Parágrafo: espaço simples. Fonte: Calibri 12. Seguida do resumo, com espaço.

Corpo do texto: Parágrafo Justificado; Recuo da primeira linha do parágrafo: 1,5; Fonte: Calibri/ tamanho 12; Espaçamento: 1,5, sem espaço antes ou depois;

Citações: Até 3 linhas, no corpo do texto com aspas. Mais de três linhas: em parágrafo recuado, à direita, em $4 \mathrm{~cm}$ da margem esquerda, espaço simples. Incluir um espaço simples antes e depois, sem aspas. Fonte: Calibri /tamanho 11. Seguir Norma ABNT 10520, disponível em http://www.trabalhosabnt.com/regras-normas-da-abnt-formatacao/nbr-10520

Notas no rodapé. Tamanho 10, justificadas.

Referências: apenas para autores citados e segundo normas da ABNT, Calibri, tamanho 11, espaço simples, com espaço de uma linha antes de cada obra citada. Justificado.

\section{DICA}

acesse http://revistaleph.uff.br/index.php/REVISTALEPH/about/submissions\#authorGuidelines

\section{POLÍTICA DE PRIVACIDADE}

Os nomes e endereços informados nesta revista serão usados exclusivamente para os serviços prestados por esta publicação, não sendo disponibilizados para outras finalidades ou a terceiros 